\title{
PENGARUH PENAMBAHAN FLY ASH DAN VOLUME FOAM TERHADAP KUAT TEKAN, DAYA SERAP AIR, DAN BERAT JENIS BETON RINGAN FOAM DENGAN PERBANDINGAN 1PC : 1PS
}

\author{
Maharani $^{1}$, Chundakus Habsya ${ }^{2}$, Anis Rahmawati ${ }^{2}$ \\ Pendidikan Teknik Bangunan, Universitas Sebelas Maret \\ e-mail: maharaniraaani@gmail.com
}

\begin{abstract}
Abstrak: Tujuan penelitian ini adalah untuk 1) mengetahui pengaruh penambahan fly ash dan volume foam terhadap kuat tekan, daya serap air dan berat jenis beton ringan foam, 2) mengetahui persentase penambahan fly ash dan volume foam pada beton ringan foam pada beton struktur ringan dengan massa jenis $800-1400 \mathrm{~kg} / \mathrm{m}^{3}$ dan kuat tekan 6,89-17,24 Mpa. Metode yang digunakan dalam penelitian ini adalah metode kuantitatif dengan desain penelitian eksperimental yang dilakukan di laboratorium. Sampel yang digunakan berupa beton ringan foam berbentuk silinder sebanyak 120 buah dengan diameter $75 \mathrm{~mm}$ dan tinggi $150 \mathrm{~mm}$. Perbandingan campuran semen dan pasir pada penelitian ini adalah 1 semen : 1 pasir (1PC : 1PS). Persentase penambahan fly ash terhadap berat pasir adalah $0 \%, 15 \%, 30 \%, 45 \%, 60 \%$. Sedangkan persentase penambahan volume foam terhadap volume beton adalah 30\%, 40\% dan 50\%. Pengujian kuat tekan, daya serap air dan berat jenis dilakukan pada saat umur beton 28 hari. Hasil kuat tekan tertinggi beton ringan foam yaitu 12,526 MPa pada beton ringan foam dengan persentase penambahan fly ash 45\% dan volume foam 30\%. Daya serap air beton ringan foam terendah yaitu 12,261\% pada beton ringan foam dengan penambahan fly ash $45 \%$ dan volume foam 30\%. Berat jenis beton ringan foam terendah yaitu $912,027 \mathrm{~kg} / \mathrm{m}^{3}$ dan tertinggi yaitu $1395,399 \mathrm{~kg} / \mathrm{m}^{3}$. Dengan demikian, beton ringan foam yang termasuk kedalam tingkat mutu beton ringan untuk struktur ringan berdasarkan SNI 03-3449-2002 adalah beton ringan foam dengan penambahan volume foam 30\% dengan penambahan fly ash $0 \%, 15 \%$, $30 \%$, dan $45 \%$.
\end{abstract}

Kata Kunci: fly ash, beton ringan foam

\footnotetext{
${ }^{1}$ Mahasiswa Program Studi Pendidikan Teknik Bangunan FKIP UNS

${ }^{2}$ Pembimbing I Ir. Chundakus Habsya, MS.Ars.

${ }^{3}$ Pembimbing II Anis Rahmawati, S.T., M.T.
} 


\title{
THE EFFECT OF ADDITION FLY ASH AND VARIOUS OF FOAM VOLUME ON COMPRESSIVE STRENGTH, WATER ABSORPTION, AND DENSITY OF LIGHTWEIGHT FOAMED CONCRETE WITH 1PC:1PS COMPARISON
}

\author{
Maharani $^{1}$, Chundakus Habsya ${ }^{2}$, Anis Rahmawati ${ }^{2}$ \\ Pendidikan Teknik Bangunan, Universitas Sebelas Maret \\ e-mail: maharaniraaani@gmail.com
}

\begin{abstract}
The aim of this research was to 1) determine the effect of fly ash and the volume of foam of compressive strength, water absorption and density of lightweight foamed concrete, 2) determine the percentage of the addition of fly ash and the volume of foam in lightweight foamed concrete for concrete lightweight structures with $800-1400 \mathrm{~kg} / \mathrm{m}^{3}$ of density and 6,89-17,24 $\mathrm{MPa}$ of compressive strength.The method used in this research was quantitative method with experimental research design that conducted in the laboratory. The sample that was used were 120 units of cylindrical lightweight foamed concrete with diameter $75 \mathrm{~mm}$ and height $150 \mathrm{~mm}$. The comparison between cement and sand of this research was 1 cement : 1 sand (1PC:1PS). Percentage addition of fly ash that used were $0 \%, 15 \%, 30 \%, 45 \%, 60 \%$ of the weight of sand. While the percentage addition of foam volume were $30 \%, 40 \%$ and $50 \%$ of the volume of concrete. The examination of compressive strength, water absorption and density of concrete was done at the age of 28 days.The results of the highest compressive strength lightweight foamed concrete was 12,526 MPa at lightweight foamed concrete with the addition of fly ash was $45 \%$ and $30 \%$ of foam volume. The lowest water absorption lightweight foamed concrete was $12,261 \%$ in the lightweight foamed concrete with the addition of fly ash was $45 \%$ and $30 \%$ of foam volume. The lowest density of lightweight foamed concrete was $912,027 \mathrm{~kg} / \mathrm{m}^{3}$ and the highest was $1395,399 \mathrm{~kg} / \mathrm{m}^{3}$.Thus, lightweight foamed concrete which was included into the standards of quality concrete lightweight structures based on SNI 03-3449-2002 was lightweight foamed concrete with the addition of foam volume $30 \%$ with the addition of fly ash were $0 \%, 15 \%, 30 \%$, and $45 \%$.
\end{abstract}

Keywords: fly ash, lightweight foamed concrete

\footnotetext{
${ }^{1}$ Mahasiswa Program Studi Pendidikan Teknik Bangunan FKIP UNS

${ }^{2}$ Pembimbing I Ir. Chundakus Habsya, MS.Ars.

${ }^{3}$ Pembimbing II Anis Rahmawati, S.T., M.T.
} 


\section{PENDAHULUAN}

Saat ini kegiatan pembanguanan infrastruktur di berbagai negara di belahan dunia sedang mengalami peningkatan yang sangat pesat. Pada kegiatan pembangunan tersebut, sebagian besar material yang digunakan dalam konstruksi adalah beton (concrete) yang umumnya dipadukan dengan baja (komposit) atau jenis lainnya.

Beton normal adalah beton yang mempunyai berat isi 2200-2500 $\mathrm{kg} / \mathrm{m}^{3}$ menggunakan agregat alam yang dipecah (SNI 03-2834-2000, Tata cara pembuatan rencana campuran beton normal).

Di Indonesia, pemilihan material bangunan yang ringan sangat dianjurkan guna meminimalisir resiko kerusakan yang diakibatkan oleh gaya gempa. Dengan menurunkan berat jenis dari beton maka dapat mengurangi berat total dari suatu konstruksi dan beban yang disalurkan ke pondasi.

Tidak seperti beton biasa, berat beton ringan dapat diatur sesuai kebutuhan. Pada umumnya berat beton ringan berkisar antara 800 $\mathrm{kg} / \mathrm{m}^{3}$ sampai dengan $2000 \mathrm{~kg} / \mathrm{m}^{3}$. Karena itu keunggulan beton ringan utamanya ada pada berat, sehingga apabila digunakan pada proyek bangunan tinggi (high rise building) akan dapat secara signifikan mengurangi berat sendiri bangunan, yang selanjutnya berdampak kepada perhitungan pondasi (Simbolon, 2009).

Pada penelitian ini, foam ditambahkan pada mortar beton untuk menurunkan berat jenis dari beton. Sedangkan fly ash akan digunakan sebagai bahan tambah agregat halus (pasir) meningkatkan kuat tekan dan menurunkan daya serap air dari beton.

Penambahan foam pada campuran adukan beton memiliki kelemahan, yaitu akan mengurangi kekuatan tekan dan meningkatkan daya serap air pada beton. Sehingga dalam pembuatan beton ringan foam, perlu penambahan agregat atau bahan lain yang dapat mengisi pori-pori tersebut untuk meningkatkan kembali kuat tekan beton. Salah satu bahan alternatif yang dapat digunakan yaitu abu terbang (fly ash). 
Menurut Susanti (2011:64), abu terbang atau fly ash adalah hasil sampingan dari pembakaran batu bara pada pembangkit listrik tenaga uap. Dapat digunakan sebagai bahan campuran untuk semen karena kandungan mineralnya hampir sama dengan semen. Fly ash juga dapat digunakan sebagai pengganti semen.

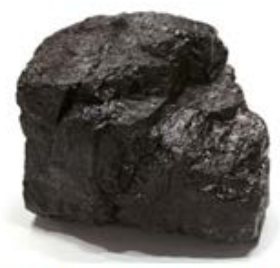

Gambar 1. Batubara Bituminous

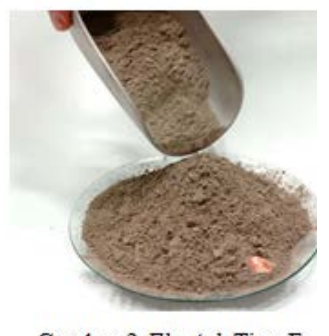

Gambar 2.Fly Ash Tipe F
(Sumber:http://lauwtjunnji.weebly.com

\section{(fly-ash--overview.html)}

Bahan tambah yang berupa bahan kimia ditambahkan dalam campuran beton dalam jumlah tidak lebih dari $5 \%$ berat semen selama proses pengadukan atau selama pelaksanaan pengadukan tambahan dalam pengecoran beton. Bahan tambah yang digunakan harus sesuai dengan standar spesifikasi yang ditentukan dalam SNI 03-2495-1991 (Susanti, 2011:41-42).
Tujuan yang hendak dicapai dalam penelitian ini adalah:

- Untuk mengetahui pengaruh mengetahui penambahan fly ash dan volume foam terhadap kuat tekan, daya serap air dan berat jenis,

- Untuk mengetahui persentase penambahan fly ash dan volume foam pada beton ringan foam yang menghasilkan beton ringan memenuhi standar mutu beton struktur ringan

\section{METODOLOGI PENELITIAN}

Penelitian ini menggunakan metode kuantitatif dengan desain penelitian eksperimental murni (true experimental) yang dilakukan di laboratorium untuk memberikan suatu gambaran mengenai pengaruh penambahan fly ash dan volume foam terhadap kuat tarik, dan berat jenis beton dengan metode campuran perbandingan 1PC : 1PS.

Persentase penambahan volume foam dari volume beton adalah 30\%, 40\% dan 50\% dengan perbandingan foam agent : air $=1$ : 40, dan variasi persentase 
penambahan fly ash terhadap berat pasir adalah 0\%, 15\%, 30\%, 45\%, 60\%. Penelitian ini menggunakan rasio volume foam agent $:$ air $=1: 40$ dengan kepadatan busa $80 \mathrm{~kg} / \mathrm{m}^{3}$.

Sampel dalam penelitian ini adalah 120 buah silinder beton ringan foam dengan diameter $75 \mathrm{~mm}$ dan tinggi 150 mm setelah umur 28 hari.

Dimana semua anggota populasi yang berjumlah 120 buah benda uji dijadikan sampel, yang terdiri dari :

1. Delapan buah benda uji yaitu masing-masing untuk beton ringan foam dengan volume foam $30 \%, \quad 40 \%$ dan $50 \%$ dan penambahan fly ash 0\% dari total berat agregat.

2. Delapan buah benda uji yaitu masing-masing untuk beton ringan foam dengan volume foam $30 \%, \quad 40 \%$ dan $50 \%$ dan penambahan fly ash 15\% dari total berat agregat.

3. Delapan buah benda uji yaitu masing-masing untuk beton ringan foam dengan volume foam $30 \%, \quad 40 \%$ dan $50 \%$ dan penambahan fly ash $30 \%$ dari total berat agregat.

4. Delapan buah benda uji yaitu masing-masing untuk beton ringan foam dengan volume foam $30 \%, \quad 40 \%$ dan $50 \%$ dan penambahan fly ash 45\% dari total berat agregat.

5. Delapan buah benda uji yaitu masing-masing untuk beton ringan foam dengan volume foam $30 \%, \quad 40 \%$ dan $50 \%$ dan penambahan fly ash 60\% dari total berat agregat.

Penelitian ini menggunakan semua anggota populasi untuk dijadikan sampel, yaitu untuk pengujian kuat tekan menggunakan 60 buah beton ringan foam dan 60 buah beton ringan foam untuk pengujian daya serap air dan berat jenis. Sampel yang digunakan untuk pengujian daya serap air dan berat jenis adalah sama, masing-masing empat buah sampel untuk setiap variasi penambahan fly ash dan volume foam. 


\section{Uji Kuat Tekan}

Kekuatan tekan adalah kemampuan beton untuk menerima gaya tekan per satuan luas. Walaupun di dalam beton terdapat tegangan tarik yang kecil diasumsikan bahwa semua tegangan tekan didukung oleh beton tersebut (Mulyono, 2003:9 dalam Fatmawati, 2013:18).

Rumus kuat tekan:

$\mathrm{P}=\mathrm{F} / \mathrm{A}$

Dengan:

$\mathrm{F}$ = gaya maksimum mesin tekan, $\mathrm{N}$

$\mathrm{A}=$ luas penampang yang diberi tekanan, $\mathrm{cm}^{2}$

$\mathrm{P}=$ kuat tekan, $\mathrm{N} / \mathrm{cm}^{2}$

\section{Daya Serap Air}

Besar kecilnya penyerapan air pada benda uji sangat dipengaruhi oleh pori-pori atau rongga. Semakin banyak pori-pori yang terkandung dalam benda uji maka akan semakin besar pula penyerapan airnya sehingga ketahanannya akan berkurang. Pengukuran daya serap air merupakan persentase perbandingan antara selisih massa basah dengan massa kering. Pengujian daya serap air ini bertujuan untuk menentukan besarnya persentase air yang terserap oleh benda uji yang direndam selama 24 jam (Septian, 2016).

Daya serap air dirumuskan sebagai berikut:

$\mathrm{WA}(\%)=\frac{\mathrm{mb}-\mathrm{mk}}{\mathrm{mk}} \times 100 \%$

Dengan:

$\mathrm{WA}=$ daya serap air $(\%)$

$\mathrm{mj}=$ massa jenuh air (gram)

mk $=$ massa kering (gram)

\section{Berat Jenis}

Pengujian berat jenis dilakukan untuk mengetahui kategori atau kelas dari beton yang telah dibuat. Berat jenis adalah perbandingan antara berat benda uji dibagi dengan volume. Untuk mengetahui berat jenis beton dapat dihitung dengan rumus sebagai berikut:

$\rho=\frac{m}{V}$

Dengan:

$\rho$ =berat jenis beton ringan foam

$\left(\mathrm{kg} / \mathrm{m}^{3}\right)$

$\mathrm{m}$ = berat beton ringan foam $(\mathrm{kg})$

$\mathrm{v}=$ volume beton ringan foam $\left(\mathrm{m}^{3}\right)$ 
HASIL PENELITIAN DAN

\section{PEMBAHASAN}

Analisis data menggunakan program komputer Statistical Package for the Social Science 23.0 (SPSS 23.0) yaitu dengan uji Regression (Regresi Linier Berganda).

\section{Kuat Tekan}

Hasil pengujian kuat tekan ratarata beton ringan foam ditampilkan pada gambar 3 .

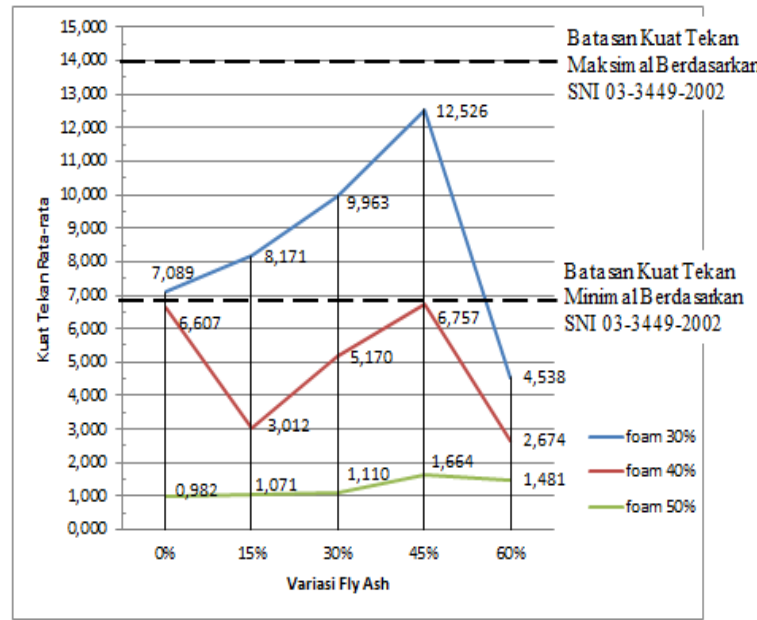

Gambar 3. Grafik Hubungan Variasi

Fly Ash dan Volume Foam terhadap Kuat Tekan Rata-rata Beton Ringan

Foam
Dari grafik hasil pengujian kuat tekan rata-rata beton ringan foam yang ditampilkan pada gambar 3 dapat dilihat bahwa:

a. Penambahan foam $30 \%$

Pada persentase penambahan fly ash dengan variasi $15 \%$, 30\% dan $45 \%$ kuat tekan beton ringan foam berturutturut meningkat. Kemudian pada persentase penambahan fly ash dengan variasi $60 \%$, kuat tekan beton ringan foam turun sebesar 7,988 MPa.

Peningkatan kekuatan tekan bata beton ringan foam dengan penambahan fly ash dikarenakan ukuran butiran fly ash yang sangat halus, yaitu 1 sampai 150 mikron sangat berpeluang untuk mengisi rongga-rongga pada bata beton ringan yang disebabkan karena penambahan foam pada campuran adukan beton. Penambahan fly ash akan meminimalisir rongga-rongga dalam beton yang menghasilkan beton menjadi lebih rapat (Ngrifin, 2015). 
Abu terbang yang butirannya lebih halus dari semen dalam mortar secara mekanik juga akan mempengaruhi kuat tekan mortar karena akan mengisi pori-pori yang ada dalam mortar sehingga menambah kekedapan dan memudahkan pengerjaan, hal ini sesuai dengan pendapat Sofwan Hadi (2000) dalam Agung (2011) yang menyatakan bahwa abu terbang dapat menambah workability dan kualitas mortar dalam hal kekuatan dan kekedapan air. Kuat tekan mortar yang paling optimal didapatkan pada prosentase $10 \%$.

Sedangkan penurunan kekuatan tekan beton dengan penambahan fly ash $60 \%$ terjadi karena faktor air semen yang dipakai pada pelaksanaan praktek meningkat yaitu menjadi 0,4 sedangkan sebelumnya menggunakan faktor air semen 0,35 karena semakin banyak penambahan fly ash maka air yang diserap semakin banyak karena fly ash memiliki struktur amorf. Pada saat faktor air semen
0,35 adukan beton menggumpal, sedangkan adukan beton yang menggumpal dapat memecahkan foam, sehingga nilai faktor air semen kemudian dinaikkan menjadi 0,4.

Menurut Gunaedi dan Hidayat (2012) dalam penelitiannya tentang fly ash sebagai subtitusi parsial pasir pada campuran beton menyatakan bahwa semakin besar kadar fly ash maka kadar air yang dibutuhkan juga semakin bertambah, sehingga hal ini mempengaruhi nilai fas yang mengakibatkan kuat tekan beton mengalami penurunan saat melewati kadar fly ash 15\%.

Fly ash sebagai filler dapat mengisi rongga-rongga pada campuran beton sehingga beton menjadi lebih padat dan kuat, tetapi semakin besar kadar fly ash akan menurunkan nilai slump. Hal ini terjadi karena fly ash lebih banyak menyerap air jika dibandingkan dengan semen, sehingga adukan menjadi lebih kering yang kemudian 
mempengaruhi nilai slump beton menjadi semakin rendah seiring bertambahnya kadar fly ash yang digunakan (Pujianto, A., 2010 dalam Gunaedi dan Hidayat, 2012).

b. Penambahan foam $40 \%$ Pada persentase penambahan fly ash dengan variasi $15 \%$, kuat tekan beton ringan foam turun sebesar 3,745 MPa. Kemudian berturut-turut naik pada persentase penambahan fly ash dengan variasi 30\% dan $45 \%$, lalu turun lagi sebesar 4,250 MPa pada persentase penambahan fly ash dengan variasi $60 \%$.

Penurunan kekuatan tekan beton pada persentase penambahan fly ash dengan 60\% karena faktor air semen yang dipakai pada pelaksanaan praktek meningkat yaitu menjadi 0,4. Seperti yang telah dijelaskan sebelumnya bahwa fly ash memiliki struktur amorf sehingga semakin banyak penambahan fly ash maka air yang diserap semakin banyak.
Penurunan kekuatan tekan beton juga disebabkan karena pada tidak sempurnanya proses pengadukan campuran di dalam mesin mixer sehingga mortar kurang homogen. Pada saat penuangan mortar ke dalam cetakan terlihat sisa-sisa pasir mengendap di dasar wadah yang artinya terjadi segregasi pada mortar. Hal ini menyebabkan kurangnya kepadatan beton ringan foam yang dihasilkan sehingga kekuatan beton uji ikut berkurang.

Menurut Warani (2014) dalam penelitiannya tentang penambahan styrofoam dan fly ash pada beton ringan, fly ash berdampak meningkatkan kuat tekan beton namun jika penambahan terlalu berlebihan maka akan mengakibatkan penurunan pada penambahan fly ash 40\%. Hal ini karena, jumlah semen yang semakin sedikit tidak mampu merekatkan bahan penyusun beton yang lain, sehingga ikatan tidak sempurna 
dan akibatnya kuat tekan beton menjadi menurun.

c. Penambahan foam $50 \%$

Kuat tekan beton ringan foam berturut-turut naik pada persentase penambahan fly ash dengan variasi $0 \%$ hingga $45 \%$, kemudian turun pada persentase penambahan fly ash dengan variasi 60\%. Penurunan kekuatan tekan beton pada persentase penambahan fly ash dengan 60\% karena faktor air semen yang dipakai pada pelaksanaan praktek meningkat yaitu menjadi 0,4.

Faktor yang menyebabkan rendahnya kuat tekan beton ringan foam adalah persentase penambahan volume foam yang tinggi yaitu 50\% dari volume beton, yang menyebabkan tingginya porositas di dalam beton sehingga beton menjadi kurang padat. Hasil fisik menunjukkan bahwa pada saat pelepasan cetakan, beton ringan foam sangat rapuh. Selain itu, setelah benda uji mencapai umur 28 hari mengalami runtuh dibagian tepi yang menyebabkan permukaan tekan tidak rata.

Berdasarkan penelitian Ngarifin (2015:111) tentang pengaruh pemanfaatan fly ash pada bata beton ringan foam, kuat tekan dengan penambahan foam 40\% mengalami penurunan yang signifikan dari penambahan foam $30 \%$.

Penurunan kekuatan tekan yang terjadi diakibatkan karena penambahan foam pada campuran adukan bata beton ringan foam yang membentuk pori-pori atau rongga di dalam beton. Dengan bertambahnya volume pori maka nilai porositas juga akan semakin meningkat dan hal ini akan memberikan pengaruh buruk terhadap kekuatan beton (Eko Hindaryanto Nugroho, 2010 dalam Ngarifin, 2015).

Hal ini sesuai dengan pendapat dari Nugraha \& Antoni (2004) dalam Wahyuni (2015) bahwa kekuatan beton juga ditentukan oleh ruang kosong atau porositas. 
Berdasarkan SNI 03-34492002, nilai kuat tekan yang dihasilkan pada penambahan volume foam $30 \%$ dengan persentase penambahan fly ash $0 \%, \quad 15 \%, \quad 30 \%$, dan $45 \%$ termasuk kedalam tingkat mutu beton ringan untuk struktur ringan yaitu 6,89-17,24 MPa. Sedangkan pada penambahan volume foam $40 \%$ dan $50 \%$ dengan seluruh variasi persentase penambahan fly ash tidak termasuk kedalam tingkat mutu beton ringan untuk struktur ringan.

\section{Daya Serap Air}

Hasil pengujian daya serap air rata-rata beton ringan foam ditampilkan pada gambar 5 .

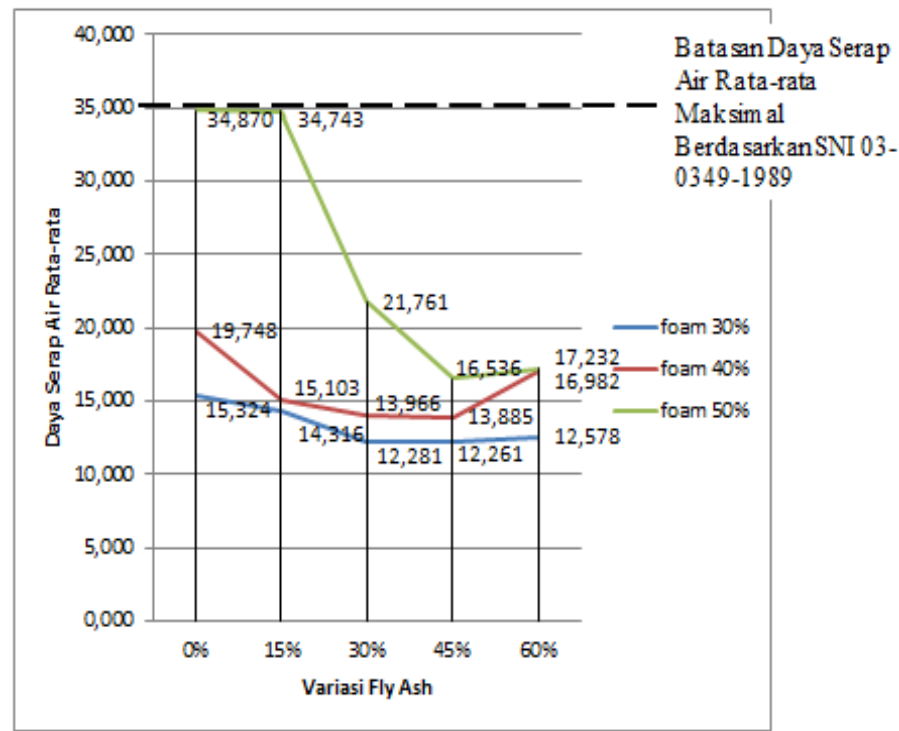

Gambar 5. Grafik Hubungan Variasi Fly Ash dan Volume Foam terhadap Daya Serap Air Rata-rata Beton Ringan Foam

Dari grafik hasil pengujian daya serap air rata-rata beton ringan foam yang ditampilkan pada gambar 5 dapat dilihat bahwa:

a. Penambahan foam $30 \%$

Daya serap air beton ringan dengan penambahan foam 30\% berturut-turut turun hingga penambahan fly ash dengan variasi 45\%, kemudian naik sebesar $0,317 \%$ pada persentase penambahan fly ash $60 \%$. 
b. Penambahan foam $40 \%$

Daya serap air beton ringan dengan penambahan foam $40 \%$ berturut-turut turun hingga penambahan fly ash dengan variasi 45\%, kemudian naik sebesar 3,098\% pada persentase penambahan fly ash $60 \%$.

c. Penambahan foam $50 \%$

Daya serap air beton ringan dengan penambahan foam 50\% berturut-turut turun hingga penambahan fly ash dengan variasi 45\%, kemudian naik sebesar 0,696\% pada persentase penambahan fly ash 60\%.

Dari gambar 5 dapat dilihat grafik hubungan variasi fly ash dan volume foam terhadap daya serap air rata-rata beton ringan foam memiliki kesamaan yaitu nilai daya serap air rata-rata turun hingga persentase penambahan fly ash 45\%. Kenaikan serapan air terjadi pada persentase penambahan fly ash 60\% karena pada persentase tersebut nilai fas yang digunakan berbeda dengan sebelumnya, yaitu sebesar 0,4. Penambahan nilai fas dilakukan peneliti karena pada persentase penambahan fly ash 60\% mortar menggumpal seiring bertambahnya penambahan fly ash.

Semakin besar persentase
abu terbang yang digunakan maka serapan airnya semakin kecil. Hal ini sesuai dengan penelitian yang dilakukan oleh Andoyo (2006), tentang penambahan fly ash terhadap mortar yang menyatakan bahwa semakin besar persentase abu terbang yang digunakan maka serapan air semakin berkurang.

Berdasarkan SNI 03-03491989, nilai daya serap air beton ringan foam yang dihasilkan pada penelitian ini dengan penambahan volume foam 30\%, 40\%, dan 50\% dengan seluruh variasi persentase penambahan fly ash masih memenuhi standar yang ditetapkan oleh SNI 030349-1989 yang mensyaratkan serapan air maksimal untuk bata beton pejal adalah sebesar 35\%. 


\section{Berat Jenis}

Hasil pengujian berat jenis ratarata beton ringan foam ditampilkan pada gambar 6 .

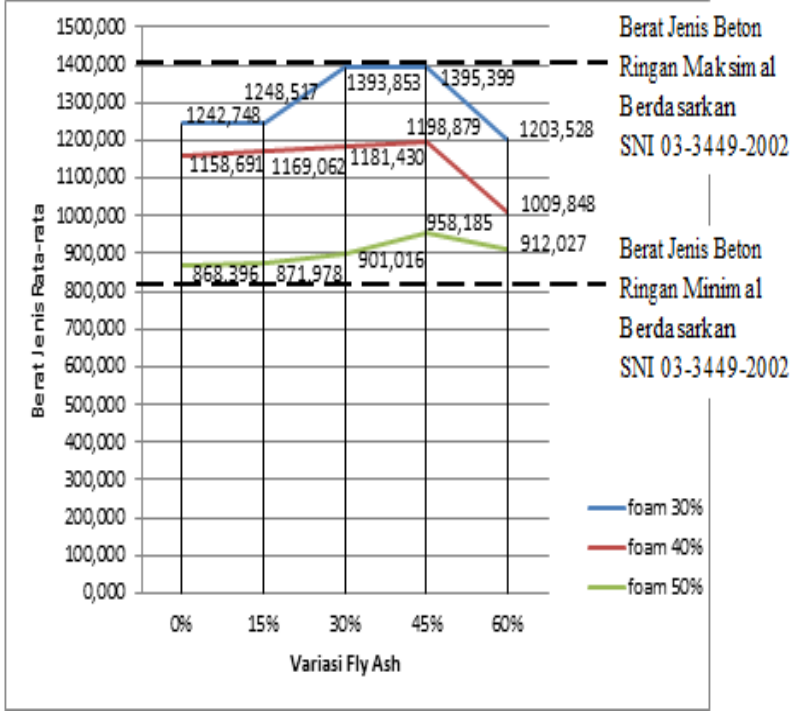

Gambar 6. Grafik Hubungan Variasi Fly Ash dan Volume Foam terhadap Berat Jenis Rata-rata Beton Ringan Foam

Dari grafik hasil pengujian berat jenis rata-rata beton ringan foam yang ditampilkan pada gambar 6 dapat dilihat bahwa:

a. Penambahan foam $30 \%$

Berat jenis rata-rata kering rencana beton ringan foam dengan penambahan foam $30 \%$ adalah $\quad 1201-1400 \quad \mathrm{~kg} / \mathrm{m}^{3}$. Sehingga berat jenis kering ratarata dengan seluruh variasi penambahan fly ash dengan volume foam $30 \%$ sesuai rencana.

b. Penambahan foam $40 \%$

Berat jenis rata-rata kering rencana beton ringan foam dengan penambahan foam 30\% adalah $\quad 1001-1200 \quad \mathrm{~kg} / \mathrm{m}^{3}$. Sehingga berat jenis kering ratarata dengan variasi $0 \%$ penambahan fly ash dengan volume foam $30 \%$ tidak sesuai rencana

c. Penambahan foam $50 \%$

Berat jenis rata-rata kering rencana beton ringan foam dengan penambahan foam 30\% adalah $800-1000 \mathrm{~kg} / \mathrm{m}^{3}$. Sehingga berat jenis kering rata-rata dengan seluruh variasi penambahan fly ash dengan volume foam $50 \%$ sesuai rencana. Penurunan berat jenis beton pada persentase penambahan fly ash dengan $60 \%$ pada persentase penambahan volume foam $30 \%$, 40\%, dan 50\% disebabkan karena faktor air semen yang dipakai pada meningkat yaitu menjadi 0,4 dari dari 0,35. Sehingga dengan penambahan 
volume foam yang sama dan nilai faktor air semen yang berbeda menyababkan berat mortar menurun maka berat jenis beton ikut menurun.

Penambahan volume foam 30\%, $40 \%$, dan $50 \%$ pada beton menyebabkan terjadinya porositas karena foam yang tercipta dalam beton menempati $30 \%$, 40\%, dan 50\% dari volume beton. Porositas ini menyebakan berat jenis beton menjadi lebih ringan. Berdasarkan SNI 03-3449-2002, nilai berat jenis beton ringan foam yang dihasilkan pada penelitian ini dengan penambahan volume foam $30 \%, 40 \%$, dan 50\% dengan seluruh variasi persentase penambahan fly ash termasuk kedalam tingkat mutu beton ringan untuk struktur ringan yaitu $800-1400 \mathrm{~kg} / \mathrm{m}^{3}$.

\section{SIMPULAN DAN SARAN}

\section{Simpulan}

penambahan fly ash dan volume foam terhadap kuat tekan, daya serap air dan berat jenis, maka dapat disimpulkan bahwa:
1. Penambahan fly ash dan volume foam berpengaruh kuat terhadap kuat tekan beton ringan foam. Penambahan fly ash berpengaruh positif terhadap kuat tekan beton ringan foam. Penambahan volume foam berpengaruh negatif terhadap kuat tekan beton ringan foam. Kuat tekan beton ringan foam semakin meningkat hingga penambahan fly ash 45\% pada setiap variasi penambahan volume foam.

2. Penambahan fly ash dan volume foam berpengaruh kuat terhadap daya serap air beton ringan foam. Penambahan fly ash berpengaruh negatif terhadap daya serap air beton ringan foam. Penambahan volume foam berpengaruh positif terhadap daya serap air beton ringan foam. Daya serap air beton ringan foam semakin menurun hingga penambahan fly ash 45\% pada setiap variasi penambahan volume foam.

3. Penambahan fly ash dan volume foam berpengaruh sangat kuat terhadap berat jenis beton ringan foam. Penambahan fly ash 
berpengaruh positif terhadap Saran

berat jenis beton ringan foam. Berdasarkan simpulan dan Penambahan volume foam implikasi hasil penelitian, maka dapat berpengaruh negatif terhadap dikemukakan saran sebagai berikut:

berat jenis beton ringan foam. 1. Perlu adanya pengembangan Berat jenis beton ringan foam penelitian lebih lanjut untuk semakin meningkat hingga persentase penambahan fly ash $45 \%$ pada setiap variasi penambahan volume foam.

4. Ada persentase penambahan fly ash dan volume foam yang menghasilkan kuat tekan maksimal sebesar $12,526 \mathrm{MPa}$ pada persentase penambahan fly ash $45 \%$ dan volume foam $30 \%$.

5. Ada persentase penambahan fly ash dan volume foam yang menghasilkan daya serap air minimal sebesar $12,261 \%$ pada persentase penambahan fly ash pemanfaatan limbah fly ash sebagai bahan tambah pasir pada beton ringan dengan penambahan volume foam 30\% dan range variasi penambahan fly ash yang lebih kecil dari penelitian ini untuk mendapatkan nilai kuat tekan, daya serap air dan berat jenis yang lebih baik dari penelitian ini.

2. Perlu adanya pengembangan penelitian lebih lanjut mengenai pembuatan beton ringan foam dengan cara perawatan sesuai Revisi SNI 03-3421-1994. $45 \%$ dan volume foam $30 \%$. 
DAFTAR PUSTAKA

Agung, Sulhan. (2011). Pengaruh

Penambahan Serat Roving pada

Mortar dengan Berbahan

Pengikat Campuran Semen dan

Kapur Tinjauan Terhadap

Angka Kelecakan, Kuat Tekan,

Kuat Tarik dan Kuat Rekat,

Skripsi. Semarang: Fakultas

Teknik Universitas Negeri

Semarang.

Andoyo. (2006). Pengaruh

Penggunaan Abu Terbang (Fly

Ash) terhadap Kuat Tekan dan

Serapan Air pada Mortar,

Jurnal. Semarang: Fakultas

Teknik Universitas Negeri

Semarang.

Gunaedi dan Hidayat, Irpan. (2012).

Pengaruh Fly Ash pada Kuat

Tekan Campuran Beton

Menggunakan Expanded

Polystyrene sebagai Substitusi

Parsial Pasir, Jurnal. Jakarta

Barat: Fakultas Teknik Sipil

Universitas Bina Nusantara.

Mulyono, T. (2005). Teknologi Beton.

Yogyakarta: Penerbit Andi.
Ngarifin. (2015). Pengaruh

Penambahan Fly Ash Terhadap

Kuat Tekan, Berat Jenis, dan

Daya Hambat Panas Beton

Ringan Foam sebagai Suplemen

Bahan Ajar Mata Kuliah

Teknologi Beton pada Semester

III PTB JPTK UNS, Skripsi.

Surakarta: FKIP Universitas

Sebelas Maret.

Nji, Lauw T. Fly Ash: Overview. Diperoleh pada 19 Juli 2016, pukul $23.01 \quad$ WIB, dari http://lauwtjunnji.weebly.c om/fly-ash--overview.html

Septian, R. (2016). Pengaruh Waktu Pemeraman terhadap Uji Kuat Tekan Paving Block dari Campuran Tanah dengan Semen Menggunakan Alat Pemadat Modifikasi, Jurnal. Bandar Lampung: Fakultas Teknik Universitas Lampung.

Simbolon, Tiurma. (2009).

Pembuatan dan Karakterisasi Bata Beton Ringan, Jurnal. Medan: Sekolah Pascasarjana Universitas Sumatera Utara. 
Standar Nasional Indonesia. (2000). SNI 03-2834-2000 Tata Cara Pembuatan Rencana Campuran Beton Normal. Badan Standardisasi Nasional.

Standar Nasional Indonesia. (2002). SK SNI 03-3449-2002 Tata Cara Perancangan Campuran Beton Ringan dengan Agregat Ringan. Badan Standardisasi Nasional.

Susanti, R. D. (2011). Teknologi Bahan Konstruksi, Buku Ajar. Medan: Institut Teknologi Medan Bekerjasama dengan Dinas Pendidikan Provinsi Sumatera Utara Subdis Pendidikan Tinggi.
Wahyuni, A. S. (2004). Pengaruh Pemanfaatan Abu Sekam Padi pada Bata Beton Ringan Foam Terhadap Kuat Tekan, Berat Jenis, dan Daya Serap Air sebagai Suplemen Bahan Ajar Mata Kuliah Teknologi Beton (pada Mahasiswa Semester III PTB FKIP UNS), Jurnal. Surakarta: FKIP Universitas Sebelas Maret.

Warani, Iqbal F. (2014). Pengaruh Penambahan Limbah Stirofoam dan Fly Ash terhadap Berat Jenis dan Kuat Tekan Beton Ringan Struktural, Skripsi. FKIP Universitas Sebelas Maret. 